\title{
Analysis of the Ethics of the Business Judgement Rule Under Section 180(2) of the Australian Corporation Law
}

\author{
Melville Miranda \\ University of Southern Queensland, Toowoomba, Australia
}

\begin{abstract}
In Apple v Orange, Austin J sought to construe the business judgement rule, stating that there are "no degree or levels of reasonableness". In this case, he said that a belief is reasonable or not reasonable. To be a "reasonable person" in the eyes of the law, a person must not hold beliefs that are not reasonable. His honour considered accepting ASIC's submission in Apple would render s180(2) of the Corporation Act 2001 otiose, failing to achieve "the drafters" evident purpose of adopting the American Law Institute formula which sets the standard at a lower level than objective reasonableness. He therefore sought to construe the phrase "rationally believe” accordingly.
\end{abstract}

Keywords: business judgement rule, director's duty of care and diligence, honesty, integtity, ethics of business, transparency

\section{Introduction}

Dictionary's definition of "rational” differs from "agreeable to reason, reasonable" to "based on, derived from reason or reasoning". His honour held that it is plausible to say that drafters of the definition of "rationally believe" intended to capture the latter idea, namely, that the (believer's) belief would be rational—if it was based on-reasoning (whether or not the reasoning convinced the judge and therefore was objectively "reasonable"), but it would not be rational-if there was no arguable reasoning process to support it. The drafters articulated the latter idea thus: "no reasonable person in their position would hold".

The paper will discuss following issues that need consideration when trying to rely on s180(2):

(1) The director must appropriately inform themselves of the subject matter of the judgement "appropriate" encompasses the material information reasonably available to the director, the time available to obtain the move, and the cost of obtaining it.

(2) The importance of the business judgement to be made. Will it have a major impact on the company?

(3) The director's confidence in exploring these matters? Do they understand the matter to be decided on? How long did the officers have to consider the matter?

(4) The state of the company's financial position at the time and the directors understanding of the company position.

(5) The competing demands on the board's attention.

Austin's J interpretation is "plausible", but whether it is correct is another question. It clearly achieves a

Melville Miranda, scholar at law, University of Southern Queensland, Toowoomba, Australia.

Correspondence concerning this article should be addressed to Melville Miranda, University of Southern Queensland, Toowoomba, Queensland, Australia. 
result which gives s180(2) relevance but it also seems to overlook the express words that defined when a belief is "rational" by reference to a standard, at first glance, of reasonableness. Despite the continued acceptance of the degree "Wednesbury unreasonableness" as a ground of judicial review, His honour rejected the idea that there are degrees of reasonableness.

Classical Friedman-Thatcher economic policy would have it that the sole responsibility of a corporation is to make a profit. Yet the corporate hunger for profits has led for increasing calls in Australia not only for regulation but for responsibility, especially when corporate irresponsibility or that of corporate directors has led to corporate downfall. Yet these directors are able to justify their decisions according to the business judgment rule, and the push to reform the business judgment rule under the previous Labor Government was predicated upon the expansion of the "safe harbour" that the rule provides rather than the imposition of ethical guidelines for the making of a business decision by the directors of a company.

The writer will then investigate the lack of ethical guidelines, and the curious position whereby the maker of an administrative position in the public sphere, down to the lowliest administrative worker in an outback shire council, is bound by far more stringent legal requirements to what is "reasonable" than is the director of a multinational company incorporated in an Australian jurisdiction, even a company which was once a state owned asset (such as Telstra or the Commonwealth Bank) or one which carries out a formerly public function (such as Origin Energy or any of the airport companies which are now privatised).

The policy underlying a business judgment rule is said to be to recognise the need for directors to engage in considered risk taking and to protect the directors when those risks are part of an informed business judgment ${ }^{1}$. But what does it mean to be informed? What does it mean to "understand the matter"? The drafters of s180(2) thought it necessary to define an irrational belief as one which no reasonable person would hold, but this is subject to some equivocation: a religious person would say that about Darwinism-it's only a theory after all—and a Darwinist would say the same about Creationists.

The Court in ASIC v Rich found that it is plausible to say that the drafters of the definition of rationally believe intended to capture this latter idea, namely that the director's or officer's belief would be a rational one if it was based on reason or reasoning. Were there no arguable reasoning process to support a belief it would not be rational? The drafters used these words to express that concept: no reasonable person in their position would hold ${ }^{2}$. What also relevant is the principle that "a finding of a jury may only be overturned if it is one that no reasonable jury could reach”3.

An ethical dilemma arises when some in a business would hold a belief and other would not. Lord Greene M. R. in Re Smith and Fawcett ${ }^{4}$ described the directors' equitable duty as encompassing the duty to act "bona fide in what they consider—not what a court may consider—is in the interests of the company, and not for any collateral purpose.” Is that all that is required to satisfy the statutory duty under s180(2)?

Although this case was decided under the equitable rather than the statutory principles, the case of Australian Metropolitan Life Assurance Company Ltd v. Ure in 1923, the court had to rule on a decision made by the board to refuse registration of a transfer of shares to someone the board thought was of a reputations which would damage the corporation's reputation if he became a director. Does this case arise today, the

\footnotetext{
${ }^{1}$ ASIC v Maxwell (2006) 59 ACSR 373; ASIC v Macdonald (No. 11) (2009) 256, ALR 199, 245 [236].

${ }^{2}$ Australian Securities and Investments Commission v Rich (2009) 75 ACSR 1 at 636 [7289].

3 John Fairfax Publications Pty Ltd v Rivkin (2003) 201 ALR 7.

${ }^{4}$ (1942) Ch. 304 at 306 (C.A.).
} 
question: "is the case supported by reasoning” would be answered "yes". Could a reasonable director (or board) exercising business judgment decide to refuse to register a transfer of shares? A refusal would not be so unreasonable that no reasonable person would agree, especially as it was supported by some reasoning.

In its review of the relevant legislation, when the Cooney Committee (1989) recommended that a business judgment rule is introduced into Australian corporations law, it is believed that the law should oblige directors to inform themselves of matters relevant to the administration of the corporation, and that directors should be required to exercise an active discretion in the relevant matter or, alternatively, to show a reasonable degree of care ${ }^{5}$. These provisions allow investors to invest in a company on the understanding that the directors will direct the corporation in the interests of its shareholders.

But what are the interests of shareholders? Shareholders invest their superannuation and nest-eggs with corporate directors on the implicit promise that they will be increased in value through a mixture of dividends and capital gains. Should directors then make their decisions with a sole view to maximising short-term profits? Or should the business judgment rule compel them to have regard for the longer-term implications of a decision for the corporation, its creditors (a statutory requirement at some times) its employees, maybe environmental or consumer matters under other legislation?

There is no "ethical judgement rule", which might justify sacrificing profit because of a concern is cautious about possible infringement of the Australian Consumer Law. Was a point to be taken about lost opportunities, could the directors produce documents demonstrating the quality of the reasoning employed in reaching their decision not to exploit an opportunity? Is it reasonable to exploit an opportunity where the chance of profit justifies the risk of being caught? For example, in ACCC v Boost Tel Pty Ltd ${ }^{6}$, an order was made requiring the respondent to send copies of the judgement and the court orders it sustained to its 20 largest competitors. Writing of corrective letters to consumers who have been misled by a course of advertisements created by the respondent was ordered against another Optus in $2010^{7}$. An order was granted in ACCC v Startel Communication Co Pty $\mathrm{Ltd}^{8}$, wherein Collier J ordered the respondent to publish information that would educate consumers as to their rights under the ACL in the context of unsolicited consumer agreement provisions.

So despite their public role, they often direct companies which use public moneys (for example managed investment schemes, banks, or companies that sell prepaid services such as telcos) and in directing organisations involved in trading with members of the public, directors are not subject to the sort of duty to which are lawyers: the duty to the court is paramount, but there is no question of conflicting duties between a lawyer's client and the court. The concept of the lawyer as an officer of the court is an acknowledgement of the role that can be described as one of the servants of a public institution. The peculiar feature of counsel's responsibility is that he owes a duty to the court as well as his client. The practitioner must not harm the administration of justice during the promotion of the client's needs ${ }^{9}$. His duty to the client is subject to his overriding duty to the court. In the performance of that overriding duty there is a strong element of public interest $^{10}$.

\footnotetext{
${ }^{5}$ Senate Standing Committee on Legal and Constitutional Affairs, Parliament of Australia, Company Directors’ Duties (1989) (Cooney Report) 31 [3.35].

6 ACCC v Boost Tel Pty Ltd [2014] FCA 352, 37-40.

7 ACCC v Singtel Optus Pty Ltd (2010) 276 ALR 102, 3.

8 (2014) FCA 352, 37-40.

9 White Industries (Qld) Pty Ltd v Flower \& Hart (1998) 156 ALR 169.

${ }^{10}$ Giannarelli v Wraith (1988) HCA 52; (1988) 165 CLR 543, 555.
} 
Barristers were enjoined not to let their enthusiasm for their client derail their judgment and lead them into unprofessional conduct in Oldfield v Keogh ${ }^{11}$. Without enthusiasm for his client's case, no specious assurance from his client that the insertion of some strong allegations will coerce a favourable settlement, without desire to fortify the relevance of his client's case, entitles the advocate to trespass, in matters involving reputation, a hair's breadth beyond what the facts as laid before him and duly vouched and tested will justify. It will not do to say lightly that it is for the court to decide the matter. It is for counsel to see that no man's good name is wantonly attacked.

The preamble to the advocacy and litigation rules, contained within the model rules affects every lawyer.

Practitioners in all their dealings with the courts, whether those dealings involve the presentation of evidence or the preparation and filing of documents should act with competence, honesty, and candour. Practitioners should be frank in their responses and disclosures to the court, and diligent in their observance of undertakings which they give...

The model rules also incorporate an expression of the general standard of conduct expected of practitioners.

A practitioner must not engage in conducting, whether in the course of practice or otherwise, which iscalculated, or likely to a material degree, to:

(a) be prejudicial to the administration of justice;

(b) diminish public confidence in the administration of justice (Law Council of Australia, Model Rules of Professional Conduct and Practice, 2002 ${ }^{12}$ ).

Such requirements do not affect company's directors. So it can return to the two ACCC cases involving the telcos. There were no facts laid before any of the directors that justified the representations. Given that neither judgment was likely to the attention of consumers, did the low risk of being caught and the small financial cost of the punishment justify the risk each of the telcos ran? In terms of a simple business case or the sort of calculus of negligence lawyers discuss in terms of the Civil Liability Acts? Company directors have no general duty to act with candour, without duty not to mislead the court, indeed without duty to behave in any conduct which is not criminal. There are no duties either proscriptive and prescriptive articulated in legislation or at common law setting out central obligations owed by directors not to sail close to the wind. The sort of argument allows a plaintiff to sue, as a bargaining chip, for many times their claim as long as there is a prospect of recovering some of it (Degiorgio v Dunn, 2005), NSW (but, arguably, not in other states) allows all sorts of conduct by directors which some would view as immoral and others simply as taking advantage of one's market position.

Is it correct to say of directors that if they ignore the interests of the community or other stakeholders, maybe in terms of long-term brand perception which is not immediately measurable in bottom-line terms, they are not acting in the best interests of the corporation. There is nothing in s180(2), which genuinely constrains directors who wish to contribute to the long-term development of their corporations by taking account of the interests of stakeholders other than shareholders, but there is nothing that compels directors to focus their attention on stakeholder's engagement or corporate social responsibility either.

In short, s180(2) is of little assistance when assessing what role ethical considerations have in business judgment as there is no requirement to consider where the corporation's long-term benefit lies, when weighed

\footnotetext{
11 (1941) 41 SR (NSW) 206.

12 Law Council of Australia, Model Rules of Professional Conduct and Practice (2002) r 12.
} 
against the market pressures of short-term impacts. Further, in the eight years since the publication of this paragraph in a report to Parliament:

There may be underlying concerns too about divergence between the social responsibility of individuals acting on their own account and the collective responsibility of individuals acting in a corporate or other organizational environment. Current interest in these matters within Australia and elsewhere is reflected in the efforts of companies themselves to explain better their own practices and contributions to society. (The Social Responsibility of Corporations, 2006)

No advances have been made towards a requirement that business judgment incorporates any ethical matters at all. This despite commentary such as: the subprime crisis and the credit crunch are, in an important sense, the result of our failure to effectively reform corporate governance after the last set of scandals (Ramirez, 2009).

There is, unsurprisingly, no equivalent of Article 14 of the Germany Basic Law (Grundgesetz or Constitution) in Australia. That law confers an obligation on corporations and others which possess property to exercise social responsibility: "Property entails obligations. Its use should also serve the public interest". The German position echoes Rubenstein's discussion of Australian citizenship as participation and membership within a democratic community, a concept which may be broader than Australian citizenship as a legal status. Kim Rubenstein (Citizenship in Australia) argues that there is a social membership of the Australian community which allows participation in democratic institutions. But there is no requirement of citizenship for corporations wishing to influence those democratic institutions and unethical decisions by business to lobby governments have been identified by the recent senate inquiry into the former Newman government in Queensland (Melinda Howells Corruption, 2015), the inquiry into certain Australian companies in relation to the UN Oil-For-Food Programme ${ }^{13}$ and the Royal Commission into Australian meat industry ${ }^{14}$.

Both short- and long-term thinking is supported by reasoning, and proponents of neither school of thought could be accused as being irrational or as adopting position that no reasonable person could hold, even if few persons would hold those views. Presumably, the thinking of each of the corporations at the heart of the three royal commissions recited above was motivated by short-term thinking designed to make a profit for the companies concerned. The directors held views that few others might have held, but none of those Royal Commissions recommended any proceedings for bad business judgment against any director of the subject companies.

Curiously, an action against AWB limited on behalf of shareholders alleging that AWB was in breach of its continuous disclosure obligations under both ASX Listing Rule 3.1 and section 674(2) of the Corporations Act succeeded with the parties reaching an in principal $\$ 39.5$ million settlement ${ }^{15}$. The shareholders pleaded that AWB had engaged in misleading and deceptive conduct by concealing the true nature of its agreements with the Iraqi Grains Board which the Cole commission found had earned AWB illicit gains ${ }^{16}$. Still, there were no prosecutions of directors for a breach of $180(2)$.

Put another way, if one looks at the facts of some of the more obvious prosecutions by the ACCC (such as Boost Telecom, supra), one might ask: "How could a reasonable group of directors have approved such a

\footnotetext{
${ }^{13}$ Conducted by T. R. H. Cole, 2005-6.

${ }^{14}$ Conducted by A. E. Woodward, 12 September 1981-21 September 1982.

15 Ray Brindal, “AWB settles in Iraq kickbacks scandal for \$39.5m”, The Australian, 15 February, 2010, available at: http://www.theaustralian.com.au/business/legal-affairs/awb-settles-in-iraq-kickbacks-scandal-for-395m/story-e6frg97x-12258305 63930.

${ }^{16}$ http://www.oilforfoodinquiry.gov.au/agd/WWW/unoilforfoodinquiry.nsf/Page/Report_Prologue.html.
} 
marketing campaign? They ought to have known that it contravened the Australian Consumer Law”. The fact is that a profit driven group of directors did approve the conduct resulting in the prosecution of Boost Telecom, basing their reasoning on short term profit.

Backed by reasoning, rational in its way, but hardly ethical.

There are limits...to the extent to which legislation can prescribe what will amount to responsible corporate decisions, just as there are limits in prescribing good behaviour by other bodies or individuals. Within the confines of the law and the context of varying interests and views within which they operate, companies have to chart their own course, just as individuals do.... What responsibility calls for in particular situations will not always be clear. It generally calls for judgment, a balancing of interests and considerations, not just a reflection of one particular viewpoint. However, companies and those who govern their affairs do not operate in a values-free zone and their activities are and should be subject to evaluation and criticism...

Questions have been raised about whether corporations have a responsibility to society going beyond their role as participants in the economic system. (The Social Responsibility of Corporations, 2006)

Some theorists reject this so-called balanced approach. Friedmanites have argued extensively against government regulation such as even the current version of s180, in their eyes, causes inefficiencies in the market and inhibits the legal making of profits (Klein, 2008). To a Friedmanite, it would appear that anything, whether the law or anything else, which gets in the way of profit is an inefficiency in the market. So Friedmanites would argue that the decisions of directors in James Hardie and the Australian Wheat Board both subjects of government inquiries in the last decade in Australia, satisfied with the business judgment rule - they made profits! Apparently, rational board members engaged in well-known companies such as Safeway ${ }^{17}$ (now part of Woolworths), Visy Packaging and Jurlique cosmetics ${ }^{18}$ engaged in illegal price fixing after reasoning their way through a decision making process focussed merely on profits.

Section 1013D(1)(1), Corporations Act 2001, requires issuers of investment products, but not shares, to include in their product disclosure statements "the extent to which labour standards or environmental, social, or ethical considerations are taken into account in the selection, retention, or realisation of the investment”. These considerations are not legislated with respect to the exercise of business judgment.

\section{The Safe Harbour Rule and Calls to Expand It}

In Ingot Capital Investments Pty Ltd v Macquarie Equity Capital Markets ${ }^{19}$, McDougall J commented that directors should only be liable in respect of bad business judgment once a consideration of the balance of risk and reward was taken into account. Some commentators think this means that the courts favour allowing directors to adopt entrepreneurial flair without persistently concerning themselves with the legal outcome, but this is not a fair reflection of the judgment, which involved misleading and deceptive conduct. The court did see that in some circumstances, it is critical that directors exhibit entrepreneurial flair and accept commercial risks to produce a sufficient return on the capital invested by shareholders, such that the mere foreseeability of harm does not of itself dictate that the question must be answered always adversely to directors. In addition, if a big chunk of capital disappears in fines or damages, there's less remaining for dividends to creditors.

Some directors have commented that the risk associated with personal liability has directly affected their decision making processes and resulted in a selection of the most conservative decision option available to

17 ACCC v Australian Safeway Stores Pty Limited \& Ors (1997) ATPR 41-562.

18 Australian Competition and Consumer Commission v Jurlique International Pty Ltd (2007) FCA 79 (8 February 2007).

19 (2007) NSWSC 124. 
them. These directors see the introduction of any additional statutory requirements, above those already contained within the CA, imposing even greater personal liability on directors in the absence of personal fault provides significant disincentives for experienced individuals from taking six companies' directorships at all (CAMAC Report, 2006). Those directors are obviously not those such as ANZ bank's Mike Smith with a executive director's fee of $\$ 10.4$ million in 2013. ${ }^{20}$

The safe harbour rule is very concerned with reliance and not at all concerned with ethics. One director cannot rely on another for guidance in financial matters - one with lesser skill who relies on one with greater skill would not be able to rely on the $\mathrm{s} 588 \mathrm{H}(3)$ defence as he did not exercise reasonable care and diligence required by a director as he failed to monitor the financial affairs of the company. ${ }^{21}$ Directors (including non-executive directors) are expected to become familiar with the fundamentals of the business in which the company is engaged and to guide and monitor the management of the company. ${ }^{22}$ A director who adopts a nonchalant attitude toward board meeting attendance is not acting with due care and diligence and is not in the best interests of the company. Such an errant director was company to be investigated, it would be likely found to have contravened s180(1) and therefore also s588G(2).

In the United States, the business judgement rule affords significantly more flexibility to directors than that of Australian counterpart. In the absence of conflict of interest, the rule protects risk-taking by corporations in a broad manner and can apply to almost any decision made by a director. The United States rule considers the director's belief that the decision was made reasonably in the best interests of the company, regardless of the objective nature of this belief (Rosenberg, 2008; Varzaly, 2008).

Nothing in the US rules requires any decision made to have an ethical content, or consideration of any factor other than the company's profitability (and possibly fairness to minority shareholders).

\section{An Analogous Situation: How Reasonable Must a Corporate Decision Maker's Decision Be?}

Because Austin $\mathrm{J}$ relied so much on concepts of what was reasonable, the writer turns to consider an analogous area of law where decisions are supposed to be reasonable: that of administrative law. This branch of law in part revolves around the making of reasonable decisions. In SZMDS, Crennan and J. J. Bell effectively applied a modified version of the test in the leading British case of Wednesbury to fact-finding; in order to impugn a decision, the state of satisfaction to which a reviewing body comes must be that the decision under review is one to which "no rational or logical decision maker could arrive on the same evidence"23.

The essence of Wednesbury is the making of reasonable decisions. Like administrative decision makers, company directors are constantly required to evaluate alternatives and make decisions regarding a wide range of matters. Just as there are different personal styles, there are different decision-making styles and different people in similar positions will make different business judgments. Decision making involves uncertainty and risk, and decision makers—-whether administrators or directors-have varying degrees of risk aversion. But

\footnotetext{
${ }^{20}$ http://www.smh.com.au/business/anz-chief-executive-mike-smiths-salary-rises-to-104-million-20131115-2xmez.html.

21 ASIC Regulatory Guide 217 “Key Principle 1" provides these as a factors ASIC will take into account in assessing whether a director was in breach of their duty to prevent insolvent trading.

22 This was established in Daniels v Anderson (1995) 37 NSWLR 438 in which it was found that "a director, whatever his or her background, has a duty greater than that of simply representing a particular field of experience” (as 500 per Clark and Sheller JJA). Also, in Group Four Industries Pty Ltd v Brosnan (1992) 59 SASR 22, it was established that a director "is not entitled to sit back in self-imposed ignorance and then seek to rely on that ignorance”.

23 SZMDS (2010) 240 CLR 611, at [128] ff.
} 
that in itself doesn't make any exercise of business judgment either unreasonable or wrong.

So how unreasonable does an exercise of judgment have to be before it is wrong? In Minister for Immigration and Border Protection v Singh ${ }^{24}$, the full court of the Federal Court applied a proportionality analysis to the refusal to adjourn, and concluded that "the refusal cannot be said to be a legally reasonable exercise of power". Greenwood, J considering a challenge to findings of fact made by the AAT with respect to liability to pay workers' compensation payments, it was happy to accept that to give inadequate weight to matters of great importance or excessive weight to a matter of little importance could give rise to a reason for a reviewing court to impugn a decision-maker's decision as being unreasonable ${ }^{25}$. Both of these decisions go beyond the decision in ASIC $\mathrm{v}$ Rich, that in essence calls upon a court to find either firstly that a particular error was committed in reasoning (presumably suggestive or unreasonableness), secondly that such reasoning, as given for an exercise of business judgment, is illogical or irrational, or thirdly that the precise nature of the error might not be apparent, but that nevertheless the exercise of business judgment "bespeaks error", because it is “unreasonable, plainly unjust”, or lacks an evident and intelligible justification.

An argument as to each of those grounds was made in Drake-Brockman v Minister for Planning ${ }^{26}$ and although that case is mainly a study of the limits of environmental law it relates to ethics insofar as it might have been ethical to investigate the intergenerational effects of the building project, the subject of that litigation, in some depth; the discussion shows that the Minister's cursory assessment, without consideration of what might have been seen as relevant scientific evidence, was not a decision which could be impugned. The decision of the minister was sound despite its failure to contribute to a sustainable Australia or to consider the social dimensions of the decision.

A court might consider that $\mathrm{s180(2)}$ has been breached in cases where "there is a mere sham or façade in which that company is playing a role, or that the creation or use of the company was designed to enable legal or fiduciary obligations to be evaded or a fraud to be perpetrated”27. Yet despite clear authority which allows the piercing of the corporate veil in cases of fraud ${ }^{28}$ and possibly unfairness not amounting to fraud (Ramsay \& Noakes, 2001), the directors of for example Boost Telecom were not prosecuted in respect of a breach of the business judgment rule.

Ethical business judgments are supposed to be win-win. The companies make profits and society benefits. Generally, there is little cost to the corporation, and an ethical decision can be justified by the application of the BJR. So if there is a benefit to society, the corporation is able to make gains as a result. Let's take the example of corporate philanthropy: When corporations make donations to charity they are giving away their shareholders' money, which they can only do if they see potential profit in it. This may be because they want to exploit a cheap vehicle for advertising, or to counter the claims of pressure groups. It may assist a corporation to avoid regulation, gain legitimacy, and access to markets and decision makers.

That's not to say that individual as opposed to corporate citizens also have some advantage of the win-win which comes from the making of ethical judgments in a social setting. The discussions of the theory of Hobbes and Locke on the social covenant from which citizenship springs are, with notable exceptions, sadly lacking in

\footnotetext{
${ }^{24}$ (2014) FCAFC 1.

25 Kelk v Australian Postal Corporation (2014) FCA 147, at (208).

26 (2007) NSWLEC 490.

27 Dennis Wilcox Pty Limited v Federal Commissioner of Taxation (1988) 79 ALR 267 at 272.

28 See Gilford Motor Co Ltd v Horne (1933) Ch 935; Jones v Lipman (1962) 1 WLR 832.
} 
practical application for individuals, however, so more theoretical guidance for corporations can not be expected. For example, according to Hoekstra (2003), Hobbes' "social contract theory" is a method of justifying political principles or arrangements by appeal to the agreement that would be made among suitably situated rational, free, and equal persons. That presumably means that for corporate citizens there should be no sharp practices even if they are on the grey side of illegal. Rawls (1999, p. 175) attempts to generalize and carry to a higher order of abstraction the traditional theory of the social contract, wherein citizens agree with eachother to adopt social and economic policies aimed at maximising the long-term expectations of the least advantaged under conditions of fair equality of opportunity, subject to the equal liberties being maintained. This is achieved by adopting a basic structure containing political, economic, and social institutions which are necessary for efficient and mutually beneficial social cooperation (Rawls, 1999, p. 175).

The common thread in these theories seems to be that citizenship-and by extension, corporate citizenship-is a covenant which ensures regularity and stability in society. The human capacity for creating such artificial order or regularity, though always limited, is the basis of Hume's notion of liberty as absence of arbitrariness. The urge towards regularity in human affairs provides both the limits (stability and authority) and the context (government) where liberty may flourish (Garrido, 2008).

As Dworkin puts it: We must describe the connection between an individual and a group that makes it fair to treat him—and sensible that he treats himself—as responsible for what it does (Stuart, n.d.).

The consensus of modern scholars in Australia is that citizenship is a form of belonging and allegiance to a body of citizens (Nolan \& Rubenstein, 2009), which brings rights and (according to some but not others) corresponding duties. The citizenry as a whole shares some common beliefs, aspirations, and values. There is a good deal of "do unto others" in that-but s180(2) does not require any consideration of these factors.

Finally, although one would expect that if a company, through its directors, acted poorly enough to allow the lifting of the corporate veil that would be by necessity a case where the business judgment rule has been breached, the leading decision in Adams, where the court shows that this is not the case. The veil cannot be lifted, and the extension of the business judgment rule will not have been breached, even in severe cases of a breach of ethics-“simply because the consequences of not doing so are unfair or even absurd”. ${ }^{29}$

\section{Conclusion}

The paper has analysed the business judgement rule in the context of Australian Corporation Law. As A. J. A. Rogers stated when discussing an asbestosis claim: "with all due humility I am bound to say that there seems to me to be something wrong with the state of the law when, in order to recover compensation for apparent asbestosis, a person in the position of the plaintiff has to mount a challenge to fundamental principles". 30

\section{References}

CAMAC Report. (2006). Treasury, how did the risk of personal liability affect the decision-making process and the decision?

CAMAC, Personal Liability for Corporate Fault. Retrieved from http://www.treasury.gov.au/content/Company_Directors_Survey/10_0.html

Garrido, D. G. (2008). The ideal of liberty in the political philosophy of David Hume University of Glasgow M. Phil. dissertation.

\footnotetext{
${ }^{29}$ Graphical Paper and Media Union v Derry Print and Another (2002) IRLR 380. See also Trustor AB v Smallbone and Others (No. 2) (2001) 3 ALL ER 987.

${ }^{30}$ Briggs v James Hardy \& Co Pty Ltd (1989) 16 NSWLR 549.
} 
Hoekstra, K. (2003). Hobbes on law, nature and reason. Journal of the History of Philosophy, 41(1), 111-120.

Klein, N. (2008). Shock doctrine. Beirut: All Prints Distributors and Publishers S.A.L.

Melinda Howells Corruption. (2015). CSG concerns highlighted in inquiry's report into Queensland's Newman government. Retrieved from http://www.abc.net.au/news/2015-03-27/senate-inquiry-report-into-newman-queensland-government-released/6354944

Nolan, M., \& Rubenstein, K. (2009). Citizenship and identity in diverse societies. Humanities Research, 15(1), 29.

Ramirez, S. A. (2009). Lessons from the subprime debacle: Stress testing CEO autonomy. Retrieved from http://ssrn.com/abstract=1364146

Ramsay, I. M., \& Noakes, D. B. (2001). Piercing the corporate veil in Australia. Company and Securities Law Journal, 19, 250-271.

Rawls, J. (1999). A theory of justice. Cambridge: Harvard University Press.

Rosenberg, D. (2008). The future of corporation risk-taking and the business judgement rule. New York: Baruch College.

Stuart, J. L. (n.d.). The moral reading of the British constitution (Ph.D. thesis, University College London, undated).

The Social Responsibility of Corporations. (2006). Report of the corporations and markets advisory committee. Canberra, Australia.

Varzaly, J. (2008). Do directors duties in Australia provide adequate scope for risk-taking? Monash Business Review, 4(3), 4. 